\title{
Šarčević 'S Humanism for the Ethics of Responsibility
}

\author{
Esko Muratović* \\ Gimnazija "Stojan Cerović" Nikšić, Montenegro
}

*Corresponding author: Esko Muratović, Gimnazija "Stojan Cerović" Nikšić, Montenegro, Email: esko.muratovic@t-com.me

\section{Conceptual Paper}

Volume 4 Issue 1

Received Date: March 04, 2021

Published Date: March 25, 2021

DOI: $10.23880 /$ phij-16000169

\section{Abstract}

In this paper we will deal with the ethics of responsibility in the context of Abdulah Šarčevićs conception of humanism with the assumption of a new world ethos that will indicate alternative possibilities for the development of differentiated forms of life and knowledge, as well as an open society for a new and different positioning of man and humanity. Pointing to a rational experience of the world and life, philosophy is presented as an open spiritual reflex to all beings, which as a view (theory) contributes to understanding ideas mentally and critically, on the basis of which values whose character is often regulatory are determined and built in terms of seeking and funding what is permanent and important to us when it comes to interpersonal relationships. However, by approaching many values in both theoretical and practical discourse, the ethical-moral discourse of valuation and values is bypassed, especially when it comes to the phenomenology of interpersonal relationships. Namely, it is first necessary to preserve the dialogue of ideas, to reconstruct their new discourse with the reflection of a new world that frees us for human, cosmocentric housing and return to what is our own, which cannot be managed in any way. This is simply not about the limits of ethical judgment, which appear when questions of justice are introduced into the game, but also of moral obligation, but also of questions concerning the sources, scope and limits of humanum violations. Namely, such an approach leads not only to an insight into the structure of human monologues, but also to the influence on interpersonal relations concerning: work and action, language and opinion, creativity and culture, sociability and history, tradition and modernity. Thus it opens a demand in the persistence of a critical redefinition of some important ethical aspects of interpersonal relations within which the differences of ethical-moral phenomena of human reality are reflected, which gave rise to different values, as well as moral-value discourses.

Keywords: Abdulah Šarčević; Ethics of responsibility; Humanism; Morality; Man; Interpersonal relations

\section{Introduction}

The humanistic specificity of the role of ethics in relation to the uniqueness of human approach to moral guidelines based on humanistic principles and values is reflected and reflected in the reperception of relations within the interpersonal world and investment in its unity and readiness for coexistence. If we keep in mind that the humanistic is an authoritarian ethics whose instinct of social perception and functionality of calculative-perfidious instrumentalization of different spectrum of actions within social relations, while 'ensuring' legitimacy within the more comprehensive layers of social being, which is often a reflection of a kind of telelogization of egoistic, then it is also clear that, on the other hand, problematizing this already historical and increasingly paradoxical ideal of human self-actualization 


\section{Philosophy International Journal}

is inconceivable without the presence and actualization of humanistic values within the broadest promoted and considered spectrum of interpersonal relations - from individual to global level. This is one of the fundamental problematic contents of Šarčević's humanistically treated man and humanity, taking into account the problematization of separate historical and social experiences that led to civilizational impasses and nihilism in relation to human aspirations for belonging, transcendence, unity, identity and orientation. in the world. In that context, the consequences of Šarčević's humanism are practically situated for an epistemic-anthropophilic transposing leveled ethics of responsibility towards the needs of social and personal standardization of the starting point from morally unenviable situations of that human, not only morally-needing-active world. ${ }^{1}$ This philosophical-ethical thought and living ideal of phronesis is constantly dynamized within the framework of his thought discourses within the world of modern and postmodern, thus classifying himself as one of the most thorough diagnosticians of humanity, who showed us that thoroughly cognitive-critical and deeply humanistic-ethical cares for humanity, revealing again the counter-ranges of epistemological reductionism. Thus, it points to the similarity of the state of today's world with the undisguised aspiration to end the history of violence, which will be suppressed by a new history of peace, freedom and truth ${ }^{2}$, which takes place beyond narcissism, schizophrenia, paranoia, psychosis, neurotic hatred and aggression ${ }^{3}$, catastrophe is preceded by an epistemological catastrophe. ${ }^{4}$ At the end of his famous interview with Šarčević, Kasim Prohić will state: "His texts are unique, both in their exceptional moral charge and in the moral philosophical energy that emanates from the texts." ${ }^{5}$ Namely, this Bosnian thinker imposes on himself the task of establishing a deeper connection with the world. of life, by

1 As part of the thematization of this research, it should first be noted that there is almost no aspect of philosophical thinking of human existence within the modern and contemporary era that philosopher, ethicist and thinker of historical changes Abdulah Šarčević did not deal with in the context of philosophical-cognitive, ethical-moral, political -social, scientificcognitive, aesthetic-value and other thought interventions present in his works, without being treated, problematized, perceived, re-examined from the center of what these categories represent.

2 Šarčević, Abdulah (2003), Politička filozofija i multikulturalni svijet: istina o istini: svijet moderne i postmoderne: u sjeni nihilizma [Political philosophy and the multicultural world: truth about truth: the world of modern and postmodern: in the shadow of nihilism], Sarajevo: Svjetlost, P. 34.

\section{Ibid., P. 34.}

4 Ibid., P. 375. Political and national narcissism, then Nazism, a world catastrophe that certainly comes from the project and dream of epistemology, which is therefore preceded by epistemological, logical and metaphysical catastrophe, with a system of cosmological linearity and logic of subordination - are fatal signs of indulgence in solipsism. the tyranny of losing reality: nature and man, physicality and spirit.

5 Šarčevič, Abdulah (1988) Utopija smisla i istina vremena [Utopia of meaning and truth of time], Banja Luka: Glas, P. 436. renunciation of philosophy, and of every political philosophy, which imagines itself to possess total and metaphysical truth. Šarčević's assumptions of a new world ethos indicate alternative possibilities for the development of differentiated forms of life and knowledge, as well as an open society for the position of man in the modern world; Šarčević says: "This and everything it contains - turning the world into an ideology, denying the essential dignity of man and opinion, obscuring consciousness through existing ways of life, the triumph of intelligence deprived of moral imperative - raises the problem of truth and freedom, struggle and death in a way which is the most difficult to give a thoughtful answer. "A good part of the theorists agree that Šarčević was" among the first - if not the first - to problematize these issues in our region, among the first to notice these present difficulties and achieve new horizons of philosophical thinking in history. which has only an uncertain future left."(Veljak, 2011, 19) With Šarčević, these issues are resolved on the basis of the principle of responsibility, not in the spirit of hopelessness and resignation, but in the spirit of the anthropophilic world and the truly critical one - which is the possibility of salvation. It is not only about man's readiness to ethically correct the irresponsible attitude towards the available potentials, in order to reduce the risk of self-destruction, with the awareness of establishing responsibility not to destroy the world irretrievably, but also the appeal to establish a jointly agreed responsibility for future generations and issues. what we leave to them. According to Šarčević, the task of philosophy is reflected in the humanistic course of its selfassigned mission of separation and witness in the arms of the reality of life, in action, trial and all ways of expressing a free communication community. It is also the basis for establishing the possibility of authentic intercultural dialogue based on humanistic philosophy. Therefore, in considering the relevance of Šarčević's philosophical research for a new humanism in the domain of ethics of responsibility, questions arise: why should a person take responsibility and, accordingly, what does it mean to be engaged in the world? What are the sufficient aspirations of the humanum today in relation to the same at the time of Šarčević's activities, and even later? Can man, as a free individual, seek and expect some future humanism out of concern for himself, but also through responsibility for the Other in rediscovering the meaning of his existence? How to raise the issue of irresponsibility in using the available opportunities? In relation to such responsibility, can a supranational public be initiated on a global level? From the point of view of the philosophical and ethical point of view of man and humanity, it seems necessary to interpret and reflect on truth and freedom, good and happiness, duties and responsibilities, rights and justice, directed not only to the permanent production of the moral universe and the human universe. and society, but also towards the cautious movement of man within the begun universe of life and nature. 


\section{Philosophy International Journal}

\section{Šarčevićss Humanum for the Ethos of Responsibility}

Even in his work Origin and meaning, Šarčević will write exactly half a century ago about "understanding the world, which reduces everything that is to the physical, to the 'thing' that can be 'bought' or 'sold', 'possessed', lies on the other side of this 'creation'." However, this comingto-consciousness alone is a necessity and at the same time the beginning of destruction; that path is 'full of memories of the earlier course', which is therefore not as possible as this or that subject action. For, this transcendence surely knows "those movements which the tiny flowers make when they open in the morning," it constitutes and preserves the primordial difference and peculiarity, the inherent measure of all that is. " 6 Therefore, "humanum is thus that primordial possibility that everything, both man and nature, appears in its measure and concretion"7 Humanum is our own truth before which, within our own historical action, we are truly open with life. Before life we become those who hold to the abstraction from the humanum which is further objectified in commodities. Sarcevic says:

"And it is also the principle not only of the reduction of everything qualitative between beings, but also of people themselves. There is, therefore, no possibility in commodity relations for man to bring to the word his property, which will not be subordinated to this objectified form, to these "nihilistic constructions." And this own and primordial, which is impossible to modulate, is realized in the opposition between matter and spirit, soul and body, belief and reason, freedom and necessity, man and nature, mind and sensibility, subjectivity and objectivity, (...) opening and producing - and this is the horizon of the world - becomes humanum: the essence of man. ${ }^{\text {"8 }}$

What is "indestructible in man" (Kafka), to which Šarčević refers, is the highest instance, which, "if we destroy, we have lost the place where we can justify ourselves, to realize our responsibility and freedom." ${ }^{\prime 9}$ Reflecting in the same book Boundaries and the moral qualification of the pace of life, he will say that we do not seek and explore the optimum for man but the maximum of the attainable. Human idolatry is thus reaffirmed in the circle of existence

6 Šarčević, Abdulah (1971), Iskon i smisao, [Origin and meaning] Sarajevo: Svjetlost, P. 12.

7 Ibid.,P.12-13. "That is why the humanum is not a narrow-anthropological" correction "and" cosmetics "of this" demon of technology "and" technical civilization. "For, then man would be an absolute that overcomes all (...) Humanum, therefore, is not the music of a demiurge man, who is full of lust, and subordinates everything to himself: everything is according to his measure, everything breathes, lasts and becomes according to him. “

8 Ibid., P. 30.

9 Ibid., P. 60. in the need of universal industry and science, which know only about bare quantities. Hence the questions: which of us can deny the traces of rational reality in world theater? Don't modern "forms of humanism" focus much more on the "harmonizing ethics of traffic"? This is how the theoretical and practical turn is reached: what was missed during social evolution is revealed. Namely, it is concluded that such a human task requires critical or negative anthropology, as well as a reconstructive and critical hermeneutics, which in Šarčević's case is an a priori assumption that other cultures are educated in terms of self-deception of human existence, which should result in historical a planetary dialogue on common issues and problems of the universal reality of life. It is a fundamental human right that people are not mere observers, but also participants in moral practice, with the aim of building and continuing a successful and humane life. In this sense, the leading normative principle of a good or just life is obligatory in the idea of humanity, which rehabilitates the principle of happiness and the idea of justice. In that context:

"With the process of total instrumentalization and dehumanization, the price for the survival of the human race", from which Šarčević often starts in his discussions, is the understanding that "man is not what he wanted to create from himself, and that ethos and humanum are actually in modern and traditional In this respect, they were paradigms of the quasi-human and quasi-moral world of the historical contextualization of destruction and nihilism as vital potentials of the mere power and powerlessness of man and humanity in relation to the gaze of the meaning of existence and survival of the human world and nature. The modern ethos, claims Šarčević, no longer has anything to do with housing. It is known that ethos, above all, means that. On the path of truth towards self-deliverance must be built, which means self-formation, self-realization." 10

To talk about the ethos of responsibility in general, the ethos of love is inevitable, says Šarčević, who serves us to recognize, determine, and in happy circumstances, burn fundamentalism in our minds, because "the task of philosophy is anti-fundamentalist; and in a more original sense to move away from the previous position, because we are able to believe that there are good reasons for refuting it. ${ }^{11}$ This ethos of love invoked by Šarčević is an insurmountable hope that is not subject to metaphysical coercion. Coming to oneself or realizing humanity as a quality of meaningful and

10 Muratović, Esko (2020), Humanizam i egzistencijalizam kao humanizam: Abdulah Šarčević i Jean-Paul Sartre [Humanism and Existentialism as Humanism: Abdulah Šarčević and Jean-Paul Sartre], Filozofska istraživanja, Filozofski fakultet u Zagrebu, 159 Vol. 40 Sv. 3 (611632), str. 614 .

11 Šarčević, Abdulah (2003), Politička filozofija i multiklturalni svijet [Political Philosophy and the Multicultural World], Sarajevo: Svjetlost, str. 41. 


\section{Philosophy International Journal}

successful life - humanum (Otfried Höffe) - is understood as a certain quality of life relationships and life processes. Recognizing this as opening new horizons in the approach to what we call condicio humana ${ }^{12}$, Šarčević will, by advocating the question of legitimacy strategies and humanities strategies, give importance to critical discussions with all that is important in metaphysical and political modernity, recognizing them as open to the power of judgment. Because the idea of humanity must not be equated with the realization of humanity, which is especially present in highly developed ethical teachings, when it comes to the ethical and pragmatic dimension of practice and human life, while moral action, in the process of interaction and communication and in everyday sociocultural context, the content is achieved by the unconditional task of homo humanus. By considering the position of man in the modern world, it is necessary to point out the peculiarity of Šarčević's philosophy in the domain of the organization of a new ethics for universalist humanism and transhumanism. ${ }^{13}$ Thus, transpersonal responsibility translates into transhumanism, which, above all, can illuminate the historical state of mind in its most complete moral dimension. Moral consciousness depends on epistemological-moral views when the context of a given issue or problem is philosophically and ethically interpreted, so every ethical aspect in Šarčević who points out and points to practical implications from theoretical discourse is, in fact, the ethics of discourse.

The possibility of returning man to nature and nature to man $^{14}$, the possibility of restoring humanity to man and man to humanity, was given only in the human revolution - only then will the relationship of people (humanitas) appear as a relationship between things, as a realized, fetish relationship, because by returning to the humanum, to its own essence - and thought becomes free and active, while man who preserves nature, producing it allows and came to speech. If it preserves it in its unique and open individuation, then nature also preserves the humanum. It is a fundamental human right that people are not mere observers, but also

12 Šarčević, Abdulah (1990), U labirintu samoće [In the Labyrinth of Solitude], Sarajevo: Svjetlost, str. 203-369.

13 Jurić, Hrvoje (2018), Iskušenja humanizma [Temptations of Humanism], Hrvatsko političko društvo, Zagreb, str. 10. In order to have an idea of what we should (understand) by this term, we will use the interpretation of Hrvoje Jurić, who said in the preface to his book Temptations of Humanism: "The history of all mankind, seen as a history of humanization and universalization is a history of hope and disappointment, but these ups and downs could not have been had it not been for the solid ground given that this was happening. (...) I believe that this is the strongest foundation or, in other words, the broadest framework for the salvation and progress of humanity because it is about thinking about man and human freedom, which is focused on action and change

14 Šarčević views nature as the guardian of the humanum, because physis as the humanum is neither a property of things nor their "substance", but a creative origin of history that never materializes in its self-concealment. participants in moral practice, with the aim of building and continuing a successful and humane life. In that sense, the leading normative principle of a good or just life is obligatory in the idea of humanity, which rehabilitates the principle of happiness and the idea of justice.

Šarčević does not see humanity as a moral, honest and open consciousness, but believes that it is something more: it is a man as a giver, a producer of an independent, unique life that lives only for a human man. However, if man is alienated by the products of his labor - in goods, money, capital - if he is alienated from production itself, he is alienated from his intimacy, (to nature, to oneself, to another man). Behind everything is the truth ${ }^{15}$ that is what makes man human - it is an event in his ecstatic essence. ${ }^{16} \mathrm{~A}$ true man, says Šarčević, is one who is not a prisoner of what he has done himself and who, through what he has not yet done, gives the example of a responsible actor; one should become aware of the hidden and great power of the possible. Only true consciousness and the maturing of freedom and humanity allow us to turn against non-freedom and inhumanity. Man's openness, which becomes an essential feature of the humanum in the world, is confirmed in the presence of the other, which is constitutive of the being of the individual, and as such transcends, surpasses the Self which meets itself in the world, which will realize, build and create itself. it can be realized without relation to other people, therefore, communication becomes a condition of existence. The general assumption of such a relation is that man is a free being. In the search for the essentially defining elements of the existing reality, Jaspers comes to the realization that in continuity, he needs to be on the path of re-imagining his own existence. This is what gives existence and fullness to existence itself, revealing the totality of human reality, which forms the depth of the connection between objective and subjective reality, united and rounded off in the form of existence. Hans Jonas defined the existence of humanity as "an always transcendent possibility that

\footnotetext{
15 Šarčević, Abdulah (1988), Čovjek i moderni svijet [Man and the Modern World], Sarajevo: Svjetlost, p. 673-674. The category of truths in Šarčević has not only epistemological or ontological but also ethical-moral value and meaning, when the philosopher becomes a metaphor for rejecting the conventions of truth which today, both technologically and politically, psychologically and ethically, manipulates everything human in us. Basically, this is the main reason for today's dilemmas and doubts: 1 . How to live in the modern world and not give up your property ?; 2 . How to be in time and not lose its ancient sources ?; 3. How else to think without being blocked by the fear of helplessness ?; 4. How can we touch things around us without succumbing to their banality and usability, availability, transparency ?; 5. How to perceive things without them becoming members of systems, organizations, in a philosophical or non-philosophical sense?

16 Šarčević, Abdulah (2005), Čovjek u savremenoj filozofiji zapada [Man in Contemporary Philosophy of the West], Sarajevo: BEMUST, p. 258. Here Šarčević sees a paradox: "Man becomes a slave to things, products. The more it produces values, the more worthless, tiny, monstrous it becomes, the more the tragic disproportion between man and his ecstatic essence grows."
} 


\section{Philosophy International Journal}

existence must keep open. ${ }^{.17}$ The priority is to preserve this possibility as a "cosmic responsibility" and represents an obligation in relation to existence. This means that such responsibility is a responsibility that takes precedence over everything else, but which implies responsibility for the Other, thus confirming the fullness of humanism based on reciprocity and harmony among people. It should be noted here that humanism, beyond action and with faith in the self-sufficiency of the humanistic commitment, with the elimination of the causes of neglect of the humanum and endangering man from other people, came to the obvious problem of achieving interpersonal solidarity. Because the humility of possibilities and reach, from dignity to the collective level of aspirations and standardized reciprocity, humanum reflects as the possibility and intimacy of direct interpersonal regulation of reality according to values and needs.

\section{On the New Ethics of Responsibility as an Ethic Of Preserving Life and the World}

Based on hans link's ethics of science and hans jonas' principle of responsibility, Sarcevic will trouble the issues of causality of scientific and technical innovation and their resulting existential orientation in the world of science and technique, of which we are part of reality and in which we are caught.

It is an ethically driven humanization of treatment with the possibilities that the achievements of science and technology provide us in order to in the recovery of the mind as an idea and an order for human and socially just suitability - came to a solution in the "sense of more responsible, wiser and more humane treatment with established technological possibilities of expansion." ${ }^{18}$ in the context of progressive scientification and technification of the world), establishes an ethics of responsibility, fundamentally equivalent to Anglo-Saxon consequentialism." ${ }^{19}$ Ethics of responsibility, as one of the most important ethical aspects of Šarčević's

17 Jonas, Hans (1990), Princip odgovornost [The Principle of Responsibility], Sarajevo: Veselin Masleša, p. 144. For the humanum of existence, Jonas says: "The existence of humanity simply means: that people live; the next commandment is that they live well. (...) Special circumstances are needed, for example the present ones, so that this primordial commandment itself, with its elementary content, must be explicit. (...) This is the primordial thing of all things that can ever become the subject of universal human responsibility. "

18 Ibid., P. 111. "In this way, following in the footsteps of Max Weber (but in the new context of advancing scientification and technification of the world), an ethic of responsibility is established, fundamentally equivalent to Anglo-Saxon consequentialism."

19 Veljak, Lino (2014) Filozofijski misliti povijest u epohi postmoderne [Philosophical Thinking History in the Postmodern Epoch], in: Proceedings of the Symposium "Abdulah Šarčević Philosophical Experience of Time (Science, Philosophy, Art), p. 16 conception of humanism, in striving to realize the idea of man, "which presupposes a sense of responsibility and freedom, above all for the future and future generations ${ }^{\text {"20 }}$ under the auspices of philosophy, free of scientism and positivism, of the analytical-positivist way of thinking, "an argument for justifying the principle of preservation"21 develops, which does not deviate from the principle of hope and the principle of emancipation. Thus, Šarčević puts the ethics of responsibility ${ }^{22}$ as a principle that implies freedom; despite the fact that we can subjectively ask ourselves whether we feel responsible, and - quite objectively - whether we are able to be responsible, "to do something for the thing itself, for example for the survival of humanity, for the meaning of human existence."23 Leaving aside the question of the interest of humanity as to whether it should survive or not, the following important questions follow: how and by what means can this interest be legitimized? Who can express it? Is it dangerous to characterize this interest in the survival of humanity, and can it, Šarčević wonders, turn into a kind of theoretical and practical totalitarianism?

Although Šarčević's ethical reflections tend towards independence from finally ethically fixed theorems, Šarčević was well aware that in this way the binding ethics of responsibility should expose a new bold moral experience, showing that he adheres to it, because only in this way can a different reality be thought. move things for the better. It also implies the kind of responsibility that concerns the hypoleptic ethics of uzalism. ${ }^{24}$ It is necessary to notice the separation of the interindividual side of this ethic, and the understanding of the international organization of joint responsibility with the remark that man has come to great

20 Šarčević, Abdulah (2005) Filozofija i etika; Suvremena filozofija svijeta života [Philosophy and ethics; Contemporary philosophy of the world of life], Sarajevo: BEMUST, str. 27

21 Ibid., P. 27. "For Jonas as well as for many others who think like him, the principle of preservation is not understood with the implicit or explicit assumption that exists in an ecological ethic that the maintenance of the human species is necessary. No matter how plausible and attractive the principle of preservation in ecological ethics is, Jonas's orientation is above that towards maintaining "such conventions and institutions of the human cultural tradition, which should be considered, measured by the ideal measure of discourse ethics, as unsurpassed achievements."

22 Šarčević, Abdulah (2007), Filozofija i znanost [Philosophy and Science], Sarajevo: Connectum, p. 7. "The principle of responsibility, again, includes distinctions in that notion of responsibility, for example, between that purely formal, legal notion of responsibility, that everyone is responsible for what he does, that he must make himself responsible for what he does; (...) And another notion of responsibility for what should be done for something. In accordance with this notion of responsibility, we are responsible for the offspring, for everything that could appear in the future. "

23 Ibid., P. 7.

24 Ibid., P. 9. "It is quite clear that this means 'that any attempt to organize today the necessary collective responsibility of mankind for its collective activities, not only without any prospects but at the level of ethical justification is meaningless' (K.O. Apel, DuV, 171)" 


\section{Philosophy International Journal}

challenges by his own actions, when the certainty that the power over nature turns into humanity's impotence before its spontaneity the notion of man and the world that should be preserved from destruction. Šarčević states that Jonas's greatest efforts are aimed at proving that nothing should have a social privilege, especially the positivist and scientific notion of knowledge. "We will only know what is in the game if we know that it is in the game. Since this is not only a human accident, but also a notion of man, not only physical survival but also about the inviolability of being. An ethic that should preserve both must be above the ethics of reason and one ethic of awe. (H. Jonas, KV, 8)“ Responsibility understood in this way reflects the planetary situation in the framework of which scientific and technological power proves insatiable, opens new possibilities for human and life in general. The exploitation and subordination of nature to man and his needs, its subordination to the interests of the human race, the distant taking into account what is happening in nature and with nature is now turning precisely against man and humanity. Namely, everything that rules today concerns nature. This is how injustice seems to nature, man, the human race, which are also questions of philosophical, traditional ethics, ${ }^{25}$ which did not live up to such challenges, nor to such a task to control the world that grew on the foundations and surrogates of scientific and technological power. Classical ethics cannot be built as an ethics of responsibility, Šarčević is decisive, following all Jonas' reflections with starting points based on the situation of the crisis of modernity, with the awareness of how technology institutionalizes power that has fundamentally changed the pattern of human action. If the world of modern technology and science is properly considered, only in this way will we understand the question of the conditions of possibility and necessity of the ethics of responsibility, which seeks and dictates an ethical novelty - the ethics of responsibility invoked by such a new situation. Such ethics, by its tendency, is a new experience of crisis and drama of history, but also an upcoming-possible moral orientation in the scientific-technological world as a new awareness. As an experience of crisis and drama of history, the ethics of responsibility comes to consciousness, notes Šarčević as: "1) the possibility of overcoming anthropocentrism, 2) insight into the crisis of the utopia of technical and scientific progress, 3) the experience of violence against nature and man, 4) the limits of nature and human existence in general, 5 ) the far-reaching nature of the ecological crisis. This only tells us that philosophical ethics in its anthropocentric interpretation, as an ethics of simultaneity, of the close in time and space, with its imperatives was simply blinded by its principles, with Šarčević seeing as one of the central

25 Ibid., P. 13. "Here, however, it becomes clear that the old metaphysicalethical question of the relationship between need and being, the question of the existence of a moral form of life, a morality that is not limited to one area of life, but universal, because it permeates all our life situations , lifestyles, orientations - to give the question a new form and a new answer. " views that every being on Earth, even man, directed towards the preservation and development of his own existence, of his possibilities. It is the so-called idea of the coincidence of human survival with the natural order of things, from which follows the order towards a new interpretation of the human mind, its possibilities and abilities, excluding its affects, but also as a new attitude towards the essence of technology and science. Considering the far-reaching consequences in certain areas of science and technology, the dangers to the physical, human and social world, which lead to the vulnerability of nature, all this is essential that the new ethics must take into account: responsibility for the non-existent and possible for the future; as Francis Fukuyama has already said, that we did not inherit this world from our ancestors, but borrowed it from our descendants. In that sense, Šarčević says:

"This implies a critical transcendence of that social reality which mediates and enables the perversion of true human practice into technology, into "social stupidity, into a growing mastery of nature which, in the form of technical rationality, extends in human rule over men" and "over inner nature" (Adorno, Habermas). On the other hand, it requires that common social consciousness not only of the compulsion of social (capitalist) relations but of the "immanent compulsion of things," of the destiny of all men on this earth, of the disturbed balance of life whose re-establishment is the basis of human survival. the experience of history, a new awareness of emergency solidarity."26

Historical human experience tells us that the same kind of human action in different problem contexts and time situations changes its ethical meaning. It has long been known that certain scientific results can be used for both good and evil, as is the case with biotechnology, nuclear energy, etc. The starting point leads us not only to face all these issues, but, as Šarčević says, that we must accept the utopia of the power of scientific and technical civilization. Likewise, we must feel responsible for nature, pointing to man's relationship to it, which is in line with the imperative of confronting the interpretation of the contemporary situation of the technological age. This is how insights crystallize: the end point is that we must be aware of the utopia of the power of scientific and technical civilization, in order to preserve human dignity and freedom, to live with nature and in nature; to take into account the vulnerability and destruction of nature - human and extrahuman; to be aware of the byproducts of that and such influence of the modern and contemporary epoch: self-mastery, pride in success, practice of freedom in terms of managing nature, truth in terms of fruitfulness and verification process, fascination with the logic of progress and success; that in relation to various conflicts - social, national and interstate, the question of

26 Šarčević, Abdulah (1981), Iskustvo i vrijeme [Experience and Time], Sarajevo: Svjetlost, p.276. 


\section{Philosophy International Journal}

why politics did not face the gravity of the problem should be clarified; that thought must be freed from any utopian ontology. The paradigmatic imperative of responsibility should be directed towards future generations, with the awareness that there is no innocence and indifference. Here Šarčević pleads that the facts of coexistence of members of different ages lead to the principle of hope, which is, in fact, not only an order, but also a call to feel and experience responsibility for the future - that ethics is always an ethic of responsibility. This ethic should also be understood as a reaction to the deepest causes of modern crisis. Mediated by the myth of progress, these are all those revolutionary and radical changes in man's relationship to nature, but also to man. Man's interventions in nature are unnatural his integrity is vulnerable. Šarčević says that these human interventions do not know the limits of nature, that man must not endanger the play of elements, the balance of nature, that he must not introduce into it exhaustion and passion, weakness, anthropocentric madness, death lure and death, death itself, death of nature . The change of man's attitude towards nature has long ago caused, having in mind the types of knowledge and treatment of beings as a whole, a change in the nature of man himself. This is how the polarization of reality flows, as Šarčević says, and man's relationship to nature arises. Within the framework of the ethics of nature, which rejects anthropocentrism and the opinion that shows, as E. Fink said, that nothing lives more violently than man, it should be seen that 'nature in man turns against itself.' Only through the ethics of nature, when we want to understand the limits of human history of nature, ways of dealing with it in science, art, in sociocultural forms of life, it is necessary to get out of the crisis of progress of science and technology, which is unable to explain why we fell into this deceptive the destiny of the meeting of the mind, the disintegration of physis and logos, of life and humanity.

As a separate aspect within the ethics of responsibility in Šarčević, the ethics of responsibility for the Other is also present. Within the framework of his responsibility for the Other, Levinas affirmed in a similar way the idea of the humanism of another man, when, through the ethics of responsibility, he will give birth to a new subjectivity, ${ }^{27}$ which is reflected in the ethical relationship with the Other. As such, the ethical relation is unique in its kind - it does not concern intentionality, ie. previous experience. In this relation, it is necessary to simply protect the dignity and humanism of the Other. Encounter with the face of the Other $\operatorname{Man}^{28}$ it is a necessary condition of every obligation, responsibility, and thus of morality. The other is not derived

27 Emmanuel Levinas understood the subject in the original meaning of the Latin word 'sub-iectus', as that which is sub-inserted or sub-done.

28 Levinas, Emanuel (1998), Među nama [Between us], Sremski Karlovci Novi Sad: Izdavačka knjižarnica Zorana Stojanovića, p. 53. from my own self, but is there, always given, before me, and I am responsible for it. The preform of every responsibility, Jonas will say, is the responsibility of man for man - if we are responsible for someone, then we are also someone's responsibility; what determines the essence of the existing man is one 'need' "his causally capable quality of the subject as such carries with it an objective obligation in the form of external responsibility. ${ }^{\prime 29}$ With the fact that there are no certain clear, obvious responsibilities, when the 'real need' does not correspond to the 'always real need', man, although a moral being, does not become moral. This brings with it ethical reflection on socio-political implications with an awareness of the inevitability of moral conflicts „innate” in interpersonal relationships, which opens the need for moral and value revision of the nature of discriminatory patterns that „Other" and „otherwise” admit into their moral horizons. at best as an object, which also objectifies his existence and makes him / them a mere passive, manipulative object. In the ethics of responsibility of this Bosnian thinker constantly participates and is indicative of the notion of the human race which is given a basic moral sense based on dignity, which is given to every man by birth: to be responsible means to be responsible for the Other and Different, without which the universalization of human values which humanize and generate (re) shaping ethical and moral worldviews with a vision and possibilities of reaching and achieving life in peace among peoples and nations.

Šarčević, therefore, focused especially on the definition of man and humanity in the spirit of ethically-anthropophilically thought world and life, with an emphasis on unrecognized phenomena of morality and moral responsibility, social and political freedoms and discrimination, which in terms of critical exposure will overcoming the most obvious prejudices and misconceptions of modern man and humanity. The whole essence of the inner cognition of the world captures the very basis of all transcendence, which is seen through the eyes of human existence. Man must not be a world unto himself as someone who is closed but should always be present in the world of human events. Man has no other legislator than himself, so in incompleteness and intoxication he will make a decision about himself through self-conversion, - 'always looking for a goal outside himself.' Such humanism contains an explicit order - to have responsibilities in philanthropy.

\section{Concluding Remarks}

That Šarčević repeatedly and consistently brought the totality of his mental engagement to the altar of trust in man does not need to be proven, as evidenced by the words of

29 Hans Jonas (1990), Princip odgovornost [The Principle of Responsibility], An Attempt at an Ethics for Technological Civilization, Sarajevo: Veselin Masleša, p. 143. 


\section{Philosophy International Journal}

many contemporary thinkers and theorists, among whom Ivo Komšić will write: "Abdulah Šarčević is one of the most prolific and influential philosophical creators in the former Yugoslavia. In his works he leads an uninterrupted dialogue with the philosophy of modernity and postmodernity, both with the tradition of Western philosophy and with the philosophies of the East, discusses the theory of science and art, discusses possibilities of a new humane and more desirable ethics in the conditions of decomposition and crisis of modern scientific and technical civilization. ${ }^{30}$ His ethics of responsibility resides in ethos and humanum as the origins of moral notions of man and his historical experiences without moralistic reduction of ethics in the postmodern time, when his humanistic vision again tests the fullness of philosophical thought which in a way opposes the "values" of the modern world and society. from (self) destruction, while Šarčević calls this crisis in the world a 'mega crisis of the world'. From his discussions and polemics with the most important thinkers of the modern and contemporary philosophical tradition of teleological anticipation of reviving the progress of the human world, when historical ties between the unity of humanity and cosmopolitanism, the values of knowledge and reason are sought, a humanistic aspiration for happiness and mutual cooperation of humanity grows. actualization of the issues of human dignity, excellence and justice, as well as personal and public freedoms, which can only reaffirm the values of the human being. One of the important features of Šarčević's humanism is anti-dogmatic cultural universalism, which is reflected in a kind of transcultural philosophy of values, which crystallizes two important aspects of his ethics of responsibility: first, that his ethics of responsibility is not conditional on one-way sub-responsibilities; and another, which indicates to us that his ethics of responsibility appeals to the establishment of universal arsins of justice. His call to the ethics of responsibility situates his humanism in the historical coordinates of a needy world ethics to which man and his progress will be the goal and measure of universal moral considerations within the ethical categories of responsibility, duty, need, when often moral and any other normative in relation to cognition and to the needs of human existence, whose fundamental questions can be spoken of only with the mediation of human responsibility as a source of passionate action and a strong affirmation of human capacity to shape the human and build a more human world.

30 Komšić, Ivo (2014), Abdulah Šarčević - filozofsko iskustvo vremena (filozofija, znanost, umjetnost), u: Zbornik radova sa Simpozija: Abdulah Šarčević - filozofsko iskustvo vremena (filozofija, znanost, umjetnost), [Abdulah Šarčević - philosophical experience of time (philosophy, science, art), in: Proceedings of the Symposium: Abdulah Šarčević - philosophical experience of time (philosophy, science, art)], Sarajevo, March 30, 2011), Sarajevo: Faculty of Philosophy in Sarajevo, p. 9-14.

\section{Literature}

1. Aristotel (2003) Nikomahova etika. Sremski Karlovci Novi Sad: Izdavačka knjižarnica Zorana Stojanovića.

2. Adorno T (2001) Minima moralia, Sremski Karlovci Novi Sad: Izdavačka knjižarnica Zorana Stojanovića.

3. Apel KO (1980) Transformacija filozofije. Sarajevo: Veselin Masleša.

4. Habermas J (2017) Teorija komunikativnog djelovanja I,II, Novi Sad: Akademska knjiga.

5. Hefe O (2011) Umijeće življenja i moral. Novi Sad: Akademska knjiga.

6. Jonas, Hans (1990) Princip odgovornost, Sarajevo: Veselin Masleša.

7. Jurić H (2018) Iskušenja humanizma. Zagreb: Hrvatsko filozofsko društvo.

8. Kant I (1990) Kritika praktičnog uma, Beograd: BIGZ.

9. Komšić I (2014) Abdulah Šarčević - filozofsko iskustvo vremena (filozofija, znanost, umjetnost), u: Zbornik radova sa Simpozija: Abdulah Šarčević - filozofsko iskustvo vremena (filozofija, znanost, umjetnost, Sarajevo, 30. marta 2011.). Sarajevo: Filozofski fakultet u Sarajevu.

10. Levinas E (1998) Među nama, Sremski Karlovci - Novi Sad: Izdavačka knjižarnica Zorana Stojanovića.

11. Muratović E (2019) Etička misao Abdulaha Šarčevića - etika odgovornosti, komunikativna etika, filozofska etika i etika ljudskih prava, Podgorica: ALMANAH, pp: $7,27,21,82$.

12. Muratović E (2020) Humanizam i egzistencijalizam kao humanizam: Abdulah Šarčević i Jean-Paul Sartre, Zagreb: Filozofska istraživanja 40(3): 611-632.

13. Šarčević A (2005) Filozofija i etika, Sarajevo: Svjetlost: Bemust.

14. Šarčević A (2007) Filozofija i znanost, Sarajevo: Connectum.

15. Šarčević A (1971) Iskon i smisao. Čovjek i sudbina kulture Zapada. Sarajevo: Svjetlost.

16. Šarčević A (1972) Sfinga Zapada. Zagreb: Studentski centar Sveučilišta Zagreb.

17. Šarčević A (1981) Iskustvo i vrijeme. Sarajevo: Svjetlost. 
18. Šarčević A (1974) Kriza svijeta i istina. Sarajevo: Veselin Masleša.

19. Šarčević A (1986) De homine, mišljenje i moderni mit o čovjeku, Sarajevo. Veselin Masleša.

20. Šarčević A (2005) Čovjek u savremenoj filozofiji Zapada. Sarajevo: Svjetlost: Bemust.

21. Šarčević A (1988) Čovjek i moderni svijet. Sarajevo: Svjetlost.

22. Šarčević A (1988) Utopija smisla i istina vremena. Banja Luka: Glas.

23. Šarčević A (1993) Iskustvo vremena. Zagreb: Hrvatsko filozofsko društvo.

24. Šarčević A (2000) Odvažnost slobode. Etika ljudskih prava, Sarajevo: Pravni centar FOD BiH.

25. Šarčević A (2003) Politička filozofija i multikulturalni svijet: istina o istini: svijet moderne i postmoderne: u sjeni nihilizma, Sarajevo: Svjetlost.

26. Šarčević A (1990) U labirintu samoće. Sarajevo: Svjetlost, pp: 203-369.

27. Veljak L (2014) Filozofijski misliti povijest u epohi postmoderne. In: Zborniku sa Simpozija "Abdulah Šarčević filozofsko iskustvo vremena (znanost, filozofija, umjetnost)". 